\title{
THE WRITER OF HEBREWS AS A BIBLICAL EXPOSITOR ${ }^{1}$
}

\author{
R. T. France
}

\section{Summary}

The Letter to the Hebrews stands out among New Testament writings as the one which typically 'expounds' a selected text at some length, exploring its relevance to the current situation of the readers. This article identifies seven such extended expositions within the letter, and analyses the way scripture is understood and applied in each. While the writer respected the original meaning of the text, his 'christological interpretation' leads to new and sometimes surprising applications, which may not be (or be intended to be) 'scientific exegesis', but are fully in keeping with the hermeneutical approach of the early Christian movement and of its founder.

\section{Introduction}

It may be something of a surprise to those brought up in the tradition of biblical exposition to find that the biblical writers themselves do not often seem to use other biblical texts in the same way that we have come to use their own writings. In particular, extended exposition of Old Testament passages in a expository fashion does not seem to be a characteristic of most of the New Testament writers. The Old Testament, cited frequently throughout the New Testament, is, as C.H. Dodd long ago reminded us, 'the sub-structure of New Testament theology'. ${ }^{2} \mathrm{He}$ also demonstrated convincingly that the New Testament writers were well aware that certain parts of the Old Testament were particularly rich quarries for texts which could be used to portray Christ as the fulfilment of the earlier

\footnotetext{
1The Tyndale Biblical Theology Lecture, 1996.
}

2This is the subtitle of Dodd's important study, According to the Scriptures (London: Nisbet, 1952). 
revelation, and that their use of texts from within these favoured 'text-plots' often shows significant awareness of this literary context, rather than using the words of the chosen text arbitrarily as the basis for a claim to 'fulfilment' which bore little relation to what the original author had in mind. ${ }^{3}$ But for all this awareness of context, their method of using the Old Testament is overwhelmingly by the citation of (or more usually by less formal allusion to) individual texts of a verse or two at most rather than by extended study of passages with a view to drawing out the sense of the text in its wider literary context and applying that sense systematically to their own day. First-century Christians may, of course, have engaged in such study, and the New Testament writers' focus on certain 'text-plots' noticed by Dodd suggests strongly that they did, but if so, that more systematic study has not found an overt place in the writings they have left to us.

There is, however, one book of the New Testament which seems to offer a closer analogy to modern expository preaching than the rest: that is, the Letter to the Hebrews. The interest here is not merely in the fact that this letter is saturated with the Old Testament; the same could be said of much of the rest of the New Testament. What is more distinctive of Hebrews is the way its whole argument is focused around a succession of Old Testament themes and figures, so as to draw out both the continuity and the discontinuity between the Old Testament period and the time of fulfilment in Christ. In the course of that presentation, a number of Old Testament texts gain particular prominence, and the way in which they are handled seems sufficiently distinctive to justify this study.

\section{Hebrews as a homily or homilies?}

There is at least a superficial justification for considering the writer to the Hebrews as a preacher in that he ${ }^{4}$ describes his

\footnotetext{
${ }^{3}$ This is the argument of According to the Scriptures as a whole, and has been widely accepted.

"In referring to the unknown author as 'he' I do not wish to rule out the possibility of a female author. Harnack's proposal that the writer was 
writing as a 'word of exhortation' (13:22). ${ }^{5}$ (The fact that he also describes his writing as 'brief' raises interesting questions as to the scale of 'words of exhortation' to which he and his congregation may have been accustomed!)

On this basis it has become commonplace to discuss the possibility that this book with its very formal opening and lack of introductory greetings ${ }^{6}$ in fact began life not as a letter but as a homily or sermon which was written up and sent out with appropriate greetings added at the end to turn it into a letter, though without the writer feeling the need to make a similar conventional addition at the beginning. Notable among such accounts is that of G.W. Buchanan, who boldly describes Hebrews 1-12 as a whole as 'a homiletical midrash based on Ps $110^{\prime}$, composed before $\mathrm{AD} 70$, and subsequently turned into an 'epistle' by the addition of chapter 13.7 It may be questioned whether Buchanan is right to use the term 'midrash' here, since there is an obvious difference in method between the standard midrashic form of continuous comment on an extended passage (however richly flavoured with biblical materials drawn from elsewhere by association) and the essentially thematic argument of Hebrews as a whole (however much it may from time to time focus around a given Old Testament passage). We shall return later to the centrality of Psalm 110 in the argument, rightly noted by Buchanan, but for the moment we note the proposal that Hebrews began life as a single

Priscilla is certainly worth considering, in the light of the importance of Priscilla in the New Testament church and in particular her role in instructing the great Apollos in the Christian faith (Apollos himself being of course one of the most favoured candidates for authorship of this letter in recent scholarship). But to write 'he/she' every time the author is referred to would be tedious, and I have therefore adopted the generic use.

${ }^{5}$ The same term is used for a synagogue homily in Acts 13:15. For the term and its background see L. Wills, 'The form of the Semon in Hellenistic Judaism and Early Christianity', HTR 77 (1984) 277-99.

6In this it is paralleled among the New Testament epistles only by the First Letter of John.

${ }^{7}$ G.W. Buchanan, To the Hebrews (New York: Doubleday, 1972) XIX. Buchanan suggests (243-45) that chapter 13 was added at a later date in order to qualify the book for inclusion in the canon as an 'epistle', in reaction against Marcionite teaching. 
homily, preached or written. 8 Others have come to similar conclusions, notably W.L. Lane, who strongly emphasises its oral character: 'Hebrews is a sermon prepared to be read aloud to a group of auditors who will receive its message not primarily through reading and leisured reflection but orally.' 9

A refinement of this approach is the proposal of R.N. Longenecker, 10 developing an earlier suggestion of G.B. Caird, 11 that we have here not one sermon but five. He analyses the main part of the letter as a series of five biblical 'expositions', to which the author then added chapters 11-13 as an exhortatory conclusion before sending the whole collection off to the church with which he was concerned. The five expositions are as follows:

Hebrews 1:3-2:4 expounding a 'catena' of verses, understood christologically, from Psalms, 2 Samuel 7 and Deuteronomy 32;

Hebrews 2:5-18 expounding Psalm 8:4-6;

Hebrews 3:1-4:13 expounding Psalm 95:7-11;

Hebrews 4:14-7:28 expounding Psalm 110:4;

Hebrews 8:1-10:39 expounding Jeremiah 31:31-34.

It is this more developed form of the homiletic understanding which provides the basis for the following discussion of Hebrews. We shall return to consider its strengths and weaknesses in Part IV below.

Accounts of Hebrews as an essentially homiletic document are sometimes expressed in terms of the author's reuse of existing sermonic material. But such a proposal must face the objection that the content of the letter seems at several points not to consist of readily 'transferable' homiletic material,

${ }^{8}$ See also, e.g., F.F. Bruce, The Epistle to the Hebrews (London: Marshall, Morgan \& Scott, 21990) 25-26. A full discussion of this view, together with a valuable account of scholarly debate on the 'homily' genre in Jewish and classical literature, is offered by W.L. Lane, Hebrews 1-8 (Dallas: Word, 1991) lxix-lxxv.

${ }^{9}$ Lane, ibid, lxxv.

10R.N. Longenecker, Biblical Exegesis in the Apostolic Period (Grand Rapids: Eerdmans, 1975) 175-85.

${ }^{11}$ G.B. Caird, 'Exegetical Method of the Epistle to the Hebrews', Canadian Journal of Theology 5 (1959) 47-51. 
but to be very specifically geared to the particular circumstances in which the readers 12 found themselves, and to counteracting the temptation to 'fall away' which they were confronting (see especially Heb. 5:11-6:3; 6:9-12; 10:32-34; 12:4). Hebrews is not an abstract treatise, but a sustained piece of pastoral trouble-shooting, deliberately targeted at a congregation with a particular problem. A sermon or sermons originally preached in a different church context would be unlikely to transfer so easily into a written exhortation to this specific church. If Hebrews is indeed a sermon or sermons, that sermon seems to have been tailor-made, rather than brought out from stock. ${ }^{13}$ At the least any existing material which has been reused in this composition has been reworked and given a more specific application for its present purpose.

Longenecker's proposal of five biblical 'expositions' in the letter may seem surprising in the light of the clear and impressive coherence of the letter as we have it. It is a sustained and carefully-planned piece of argument from beginning to end. Longenecker does not appear to envisage, however, that each of the five sections in his outline represents an independent 'sermon' separately delivered and to an audience different from that to which the letter as we have it is addressed. His analysis is rather an attempt to explain the character of the successive sections which make up the one consistent argument, each of which is designed to show how one key text of the Old Testament throws light on the situation and pastoral needs of his readers. How the author came to compose a letter with such an 'expository' style of argument is not the focus of Longenecker's discussion.

This article takes its cue, twenty years later, from Longenecker's proposal. At some points I wish to modify his

\footnotetext{
12In view of the homiletical character of the material in Hebrews it might be more correct to speak of the 'hearers or readers', but to do so regularly would become cumbersome. From this point on, therefore, 'readers' implies also 'hearers'.

${ }^{13}$ This is clearly recognised by Lane, who regards the author as one who would have preferred to have addressed his hearers directly $(13: 19,23)$ but was 'forced by geographical distance and a sense of urgency to reduce his homily to writing', so that it is composed directly for the situation of his intended readers (Hebrews 1-8, lxxv).
} 
analysis, on the one hand by disputing the appropriateness of one of his proposed 'expositions', and on the other hand by suggesting that other similar expositions may be found in the letter after the point where Longenecker's analysis stops. But essentially my intention is to underline his insight that in the argument of Hebrews we see a first-century example of a Christian expositor whose instinct it was to develop his argument by focusing successively on a number of key texts, and in each case not simply to quote it and pass on, but to stay with it, exploring its wider implications, and drawing it into association with other related Old Testament ideas, so as to produce a richer and more satisfying diet of biblical theology than could be provided by a mere collection of proof-texts. Like a dog with a particularly juicy bone, he returns to his chosen text again and again, worrying at it and aiming to get all the goodness out of it for the benefit of his readers. In so doing, he offers us a pointer, unique in the New Testament, towards the sort of expository preaching which modern evangelicals have chosen to develop.

\section{The flow of the argument}

The traditional approach to the argument of Hebrews is based more on the content of its argument than on its literary form. This approach typically focuses on the theme of the superiority of the Son to the key figures and institutions of the Old Testament, and follows the author through a series of comparisons each designed to demonstrate that in Jesus we have now something better. This theme is clearly set out in the sonorous opening verses, where God's previous revelation through the prophets is contrasted with his recent and final revelation through the Son. The writer goes on to draw similar contrasts with the angels, Moses, Joshua, the Old Testament priesthood, the Sinai covenant and its tabernacle, and the sacrificial system, before drawing his argument together with reflections on the implications of the finality of Christ for the life of discipleship.

Such an understanding of the letter is normally linked with the assumption that the readers are Jewish Christians 
who, under the pressure of persecution and ostracism by the Jewish community, are wavering in their Christian commitment and are in serious danger of apostasy. That is why the writer has to pause from time to time to utter a solemn warning of the dangers of apostasy or of losing heart (hence the five 'warning passages': $2: 1-4 ; 3: 12-4: 1 ; 6: 4-8 ; 10: 26-31 ; 12: 25-29)$. To draw back now would be disastrous, leaving no further room for repentance. It would also be incredibly short-sighted, if they accept the writer's argument for the superiority of the Son: it would be to abandon the reality for the shadows, to go back from fulfilment to type, from perfection to that which was temporary and imperfect.

Such an understanding of the argument might produce a simple analysis of the letter roughly as follows:

1. The Superiority of the Son

to the prophets $(1: 1-3)$

to angels (1:4-2:18)

to Moses and Joshua (3:1-4:13)

to the Aaronic priesthood (4:14-7:28)

to the Sinai covenant $(8: 1-13)$

to the sacrificial system (9:1-10:18)

2. A call to follow the Son in faithfulness and endurance (10:19-12:29)

3 Concluding exhortations and greetings (13:1-25).

Any such analysis must, of course, allow for a number of formal digressions (among which the 'warning passages' would be prominent), and for the gradual transitions which typically occur between supposedly separate sections, making neat divisions difficult to agree in detail. It would also have to recognise that some parts of the argument of Part 1 are developed at much greater length than others (notably by the introduction of Melchizedek as a model for the superior priesthood of the Son). But with such refinements a 'thematic' 
analysis has formed the essential basis for several commentaries and expositions. 14

Such an analysis often assumes a significant division, usually placed at 10:18, between the 'doctrinal' and the 'applied' sections of the letter, in a manner familiar from many of the Pauline letters. First the writer sets out his theological argument at considerable length, and then he draws out its pastoral implications in a shorter section which is nevertheless the main point of the letter which all the doctrinal material was designed to undergird. This is, of course, in fact an oversimplification, since one of the distinctives of Hebrews is the way in which 'exhortation is interspersed with exposition' throughout the letter, in the first part as much as after 10:18.15 But as a broad characterisation this division has appealed to many.

More recently this sort of thematic structural analysis has been less in favour, and has been challenged by schemes based rather on the formal structure of the text. The work of A. Vanhoye ${ }^{16}$ has been particularly influential, and has been the basis for a more consistently structuralist approach by $\mathrm{L}$. Dussaut. ${ }^{17}$ An interesting comparison by P. Ellingworth ${ }^{18}$ of these two analyses with that of F.F. Bruce (representing a more traditionally 'content-oriented' analysis), shows, however, that while on the surface their structural schemes appear very different, their different approaches have in fact led to the common recognition of turning-points and of the flow of the

\footnotetext{
${ }^{14}$ Among commentaries which adopt a similar structural analysis we may mention D. Guthrie, P.E. Hughes and (with much sub-division) B.F. Westcott.

15Lane, Hebrews 1-8, xc. Lane usefully discusses this feature on pp. xcixciii, and argues that in Hebrews as a whole 'parenesis takes precedence over thesis in expressing the writer's purpose. Argumentation serves exhortation...exposition provides an essential foundation for exhortation'. ${ }^{16} \mathrm{~A}$. Vanhoye, La structure littéraire de l'épître aux Hébreux (Paris: Desclée de Brouwer, 21976) and many other works; Ellingworth's bibliography lists forty-four items on Hebrews published by Vanhoye between 1959 and 1991 !

17L. Dussaut, Synopse structurelle de l'épître aux Hébreux (Paris: Cerf, 1981). 18P. Ellingworth, The Epistle to the Hebrews (Carlisle: Paternoster, 1993) 5058.
} 
argument at a significant number of points. My impression from Ellingworth's comparison is of a greater degree of convergence between rival schemes than he himself allows, and reinforces his wise comment that 'the author himself probably did not make such a sharp distinction between form and meaning as a modern linguist would make'.19

In the end it must surely be admitted that the writer did not first set out to construct a literary 'scheme' (such as the very deliberate groups of seven in the Book of Revelation) and then tailor his material to fit it, for if that were the case we might expect to see more agreement among those who now attempt to discern his blue-print from his text. Rather, like most of the New Testament authors, he developed his argument in the way he felt would communicate best with his readers, employing the verbal links, transitional sections, digressions and flashbacks which are the stock-in-trade of a good oral communicator, and progressing deliberately, but not necessarily in neat steps, towards his goal of providing the 'exhortation' which he understood to be needed. All our patient structural analyses are more or less perceptive attempts to follow this process of communication, and their variety tends to reveal more about the different predispositions with which his commentators come to their task than about the intention of the writer himself. 20

How then does the Caird/Longenecker proposal of a series of 'biblical expositions' relate to the various attempts to clarify the structure of Hebrews? As set out by Longenecker, it presupposes the 'Pauline' division of Hebrews into two sections, one doctrinal and one hortatory, with the division occurring at the end of chapter 10 rather than, as with many schemes, at 10:18. He describes chapters $1-10$ as 'the argument

${ }^{19}$ Ellingworth, ibid , 57-58. Cf. S.K. Stanley, "The Structure of Hebrews from Three Perspectives', TynB 45 (1994) 245-71 for a recent discussion of the structure of Hebrews which, while recognising the importance of formal considerations, maintains that the content is of greater structural importance.

${ }^{20}$ The various proposals are graphically presented in a chart compiled by G.H. Guthrie, summarising the findings of his 1991 dissertation, and reproduced in Lane, Hebrews 1-8, lxxxix. 
of the Letter', as distinguished from 'the exhortations of Heb. 11-13', which depend on that argument. ${ }^{21}$ Longenecker's analysis of the 'argument' of the letter from the point of view of its biblical exposition then proceeds without further reference to chapters 11-13. This sharp division would be questioned by most of the more recent structural theories, and I shall argue later that to limit the discussion of biblical exposition in Hebrews to the first ten chapters does not in fact do justice to the content of chapters 11-13.

With regard to the first ten chapters, however, Longenecker's five 'expositions' do in fact correspond quite closely to the divisions of the letter which have traditionally been observed on the basis of content. The first two expositions together correspond to the comparison of the Son with angels in 1:4-2:18; the exposition of Psalm 95 corresponds to the discussion of the Son's superiority to Moses and Joshua in 3:14:13; the exposition of Psalm 110:4 corresponds to the discussion of the priesthood of the Son in 4:14-7:28; and the exposition of Jeremiah 31:31-34 which Longenecker regards as continuing throughout 8:1-10:39, corresponds to the discussion of the Son's superiority to the old covenant and to its institutions (the tabernacle and the sacrificial system). While there is room for debate over the precise identification of section divisions, and over the combination or separation of related sections, it does appear that in broad terms the 'expositions' identified by Longenecker fit closely with the thematic approach to the structure of the letter. In other words, to say that the writer is exploring a series of examples of the superiority of the Son in relation to the key aspects of Old Testament religion and to say that he is expounding a series of chosen Old Testament texts seem to be complementary rather than competing ways of understanding the progress of the letter. To put it simply, his chosen means of establishing each successive example of the Son's superiority is apparently to find and exploit an Old Testament text from which that superiority can be established, and to use that text quite

21Longenecker, Exegesis, 175. 
extensively as the basis for developing his theological argument.

\section{Some modifications of Longenecker's scheme of five expositions}

While Longenecker's scheme broadly fits the development of thought in the letter, it seems to need modification in two main ways.

Its most obviously vulnerable point is the identification of Hebrews 1:3-2:4 as the 'first exposition', since this is in character quite different from the sections which follow. Whereas in each of the other expositions there is a single key text which provides the basis of the argument, and around which the author's thought seems to be focused, in chapter 1 the 'text' is a catena of passages, each cited only once (though Ps. 110:1 will of course recur prominently in subsequent sections of the letter), and the 'exposition' does not consist in the development of the thought of any one of them, but rather in the christological implication which the author draws from their cumulative impact. In other words, this section looks much more like a collection of classical 'proof-texts' brought together on the basis of an antecedent credal conviction, than the sort of 'deductive' exposition which we have noted to be the distinctive feature of the argument of Hebrews elsewhere.

The collection of texts in chapter 1 is not arbitrary, of course. With the exception of Psalm 104:4, which focuses on the status of angels in themselves, and not by way of direct comment on the Son/Messiah, they are all drawn from Psalms or psalm-like texts (the Song of Moses, Dt. 32, and the Prophecy of Nathan, 2 Sa. 7) which would have been accepted by his readers as describing the Messiah/Son of God22 and which

${ }^{22}$ Whether all of them would have been so accepted outside the particular Christian circles in which the writer moved is of course another matter, and one which Longenecker, Exegesis, 175-81, rightly questions. The breath-taking boldness of assuming, without argument, that the 'Lord' described in Ps. 102:25-27 is the Son could surely have been attempted so confidently only in circles where this novel 'exegesis' was already agreed. As an argument addressed to non-Christian Jews who rightly understood 
illustrate his uniquely exalted status. Underlying such an argument must be a quite sophisticated process of Christian hermeneutical development which the writer can take for granted as common ground between himself and his readers. But precisely because the hermeneutical groundwork is taken for granted, and not spelled out by explicit analysis of the text and its implications, chapter 1 differs in character from the expositions which follow in the rest of the letter, and will not be considered here as one of them. ${ }^{23}$

The other area in Longenecker's analysis which needs to be questioned is his assumption that the pattern of extended expositions of Old Testament texts comes to an end in chapter 10 , to be followed simply by 'exhortations' based on the preceding expositions. In the latter part of the letter too there are a number of further texts each of which also provides the foundation for a section of the concluding exhortations, just as the four key texts did in the first part of the letter. Nor is it quite correct to suggest that the texts in chapters 1-10 inspire only doctrinal observations whereas those in the final chapters give rise to exhortations. We have noted above that doctrine and exhortation are closely interwoven throughout the letter. While it is true that the direct application of the texts from Psalm 8, Psalm 110 and Jeremiah 31 is to doctrinal issues, the pastoral implications of that doctrine are never far from sight even before we come to chapter 11. But Psalm 95 is different, in that the immediate purpose of citing the text is to apply its direct warning, 'Do not harden your hearts', to the readers of Hebrews. This exposition is every bit as hortatory in its explicit wording, not just in its underlying implications, as anything in chapters 11-13. The question is, then, whether other texts are used in a similar way in the concluding chapters. I suggest three further expositions in the concluding chapters, two of

these words as a description of the creative power of Yahweh it would have no credibility.

23It was the inclusion of chapter 1 as a separate 'exposition' which enabled Longenecker to claim five expositions where Caird had suggested only four. I think that at this point Caird had the better of it. 
which focus on a specific text, the other on a broader image from the Old Testament. ${ }^{24}$

\section{Habakkuk 2:3c-4}

The LXX of these verses is cited in an adapted and rearranged form in Hebrews 10:37-38, with the phrase 'a little while' ( $\mu$ เкрòv öбov öбov, usually traced to Is. 26:20) substituted for the first part of v. 3. While the words of Habakkuk are not cited again, the whole of the long discussion of faith which follows in chapter 11 is in effect an exposition of this verse. The traditional chapter division, and the majestic literary form of the celebration of faith, lead many interpreters to treat chapter 11 as a separate unit without adequately noting its close connection with the text which introduces it (and indeed also with the application which follows in 12:1ff). The 'definition' of faith in 11:1 fills out the writer's characterisation of himself and his readers in 10:39 which arises directly out of the Habakkuk quotation, and the rest of chapter 11 (and its conclusion in 12:13 ) then illustrates by scriptural examples what such faith will mean in practice for his readers. The whole complex from 10:32 to $12: 3$ thus forms an extended exhortation to faith and warning against faithlessness which finds its focus in the exposition of Habakkuk 2:3-4. ${ }^{25}$

${ }^{24}$ I am pleased to find in Lane, Hebrews 1-8, cxiv-cxv, reference to an unpublished paper by J. Walters in 1989 (which I have not seen) which also proposes to expand Caird's observation of four expository sections in Heb. 2:5-10:31 by the recognition of two further expositions (of Hab. 2:3-4 and Pr. 3:11-12) in the exhortatory section of the letter. Walters' proposal thus corresponds to the first two of the three additional expositions which I am here suggesting. Where Walters apparently differs from my account is in his attempt to encompass the whole of Heb. 2:5-13:19 in an allembracing six-part structure which represents the deliberate 'rhetorical strategy' of the author. I doubt whether the writer planned his work as systematically as that.

${ }^{25}$ The recognition of this continuity places a large question mark against any structural scheme of Hebrews (including that of Longenecker) which sees a division at the end of chapter 10. There may be a formal division there, in that chapter 11 has a structural unity of its own, but in terms of the flow of argument neither the beginning nor the end of chapter 11 marks a break and a new beginning. 


\section{Proverbs 3:11-12}

The exhortation to faith in 10:32-12:3 is followed by a more specific consideration of the suffering which his readers were apparently already experiencing and which was, no doubt, a major cause of their inclination to draw back from Christian commitment. This is explained by a fairly straightforward reflection on the concept of fatherly discipline as applied to suffering in LXX Proverbs 3:11-12. The whole of vv. 7-11 derives directly from the quoted text of Proverbs, pastorally applied to their situation. This reflection then leads to a resultant exhortation to endurance in vv. 12-13. This is a much shorter and more clearly focused exposition than those which have gone before, but its character as applied expository preaching surely cannot be in doubt.

\section{Mount Sinai}

After a few further exhortations (which include another brief Old Testament example in the person of Esau, 12:16-17) the writer again turns at greater length to the Old Testament for a model to use as the basis for his final warning passage. This time he does not offer a straight quotation (though there is a loose summary quotation of Ex. 19:12-13 in v. 20b), but rather evokes by a series of allusive terms and phrases the terrifying experience of the presence of God at Mount Sinai and the awed reaction of the people to it as described in Exodus 19-20. The picture is developed through vv. 18-21, and the quaking of the mountain (Ex. 19:18) is picked up as a basis for reflection in vv. 26-28, before the impact of the whole dramatic theophany is summed up in the epigram 'For our God is a consuming fire' (o

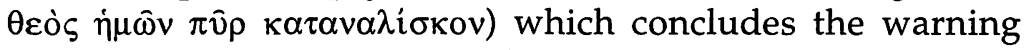
passage (12:29). But alongside the direct use of the Sinai theophany as a warning example the writer has creatively introduced an alternative mountain, Mount Sion, which stands for all that is lovely and attractive about the new relationship with God which has been opened up by the shedding of the blood of Jesus, the 'mediator of a new covenant'. Sinai therefore represents the old and frightening covenant, Sion the newly opened access to the presence of God. This is a bolder and more sophisticated use of the Old Testament text than we find in 
most of the other sections of the letter, but seems to fall well within the category of 'exposition' which we have been considering.

It may be helpful at this point to set out the sequence of seven 'biblical expositions' as I understand it, in the light of the above modifications to Longenecker's proposals. I do not believe that it is either necessary or desirable to include every part of the letter within such an exposition. While they are essential to the progress of the letter's argument, they do not in themselves form a deliberate structural scheme which must be made to account for all the content of the letter. I have therefore included under each 'exposition' only that part of the letter which seems to derive from the writer's thinking about and application of that particular text. There are therefore a number of passages (shown in the left margin) which do not fit within any of the expository sections. I have not, however, thought it necessary to mark out the digressions within an exposition (sometimes quite lengthy, notably 5:11-6:19) where the text for a time recedes from view only to reassert itself later as the basis of the writer's thought.

[Introduction:

First Exposition:

[Jesus and Moses:

Second Exposition:

Uesus the High Priest:

Third Exposition:

Fourth Exposition:

[Exhortation/Warning:

Fifth Exposition:

Sixth Exposition:

[Further Exhortations: Seventh Exposition:

[Exhortations/Conclusion:

$$
\text { 1:1-2:4] }
$$

2:5-18 on Psalm 8:4-6

3:1-6]

3:6-4:13 on Psalm 95:7-11

4:14-5:4]

5:5-7:28 on Psalm 110:4

8:1-10:18 on Jeremiah 31:31-34 10:19-31]

10:32-12:3 on Habakkuk 2:3c-4

12:4-13 on Proverbs 3:11-12

12:14-17]

12:18-29 on Mount Sinai 13:1-23]

To attempt to draw up such a table is immediately to realise how arbitrary are some of the divisions which any such analysis imposes on a text which is in fact a continuous whole. At many points a theme is pre-echoed or recapitulated, and the 
writer moves smoothly from one area of discussion into another without marking clear breaks in his argument. But these considerations give an adequate outline of the seven 'expositions' which seem to stand out as prominent features within his elaborate 'word of exhortation', and which will be the focus for the remainder of this article.

It is worth pointing out, however, that within these larger expository sections a number of other Old Testament texts are brought into the argument, some of which are themselves subjected, though more briefly, to a similar 'expository' treatment rather than being simply dropped in as self-evident proof-texts. We might notice particularly the way the story of Abraham and Melchizedek in Genesis 14 is itself exploited in some detail in 7:1-10, even though it is the subsequent mention of Melchizedek in Psalm 110:4 which has brought him into the discussion, or the way the implications of Psalm 40:6-8 are analysed in 10:8-10 after the text itself has been quoted in vv. 5-7. It seems that it was so much part of the writer's natural habit to work through the implications of a text once it was before him that even passing quotations easily turned into mini-expositions. Biblical exposition is in this book not so much a structural pattern as an all-pervasive tendency to which the writer is prone whenever opportunity offers! But for our present purposes the major expositions must suffice.

\section{The Writer to the Hebrews as a Biblical Expositor: a brief overview}

It is not possible to do justice in this article to each of these seven expositions in detail. Instead, a summary account will be given of the nature of the hermeneutical enterprise as it appears in each of the others, followed by a fuller account of how the writer has allowed one particular text, Psalm 95, to govern his exhortation in chapters 3-4. While his approach is too varied to allow any one exposition to be taken as entirely typical of the rest, the exposition of Psalm 95 offers us one fascinating insight into how a creative biblical interpreter could allow the text to 
speak in a new way into the pastoral situation of his own Christian community. ${ }^{26}$

Before working through the expositions individually, it is important to recall the overarching importance of Psalm 110 in the writer's argument. Not only does its fourth verse provide the text for his establishment of the superiority and finality of the Son as the perfect and eternal High Priest in 5:5-7:28, with explicit reference to Psalm 110:4 in 5:6; 5:10; 6:20; 7:11, 15, 17, 21, 28 , but the first verse of the psalm is also quoted or alluded to repeatedly in the letter, beginning with the concept of the Son's sitting at the right hand of God in 1:3, a concept which is then explicitly grounded in a formal quotation of the verse in 1:13, and is repeated in varying forms in $8: 1 ; 10: 12-13$ and 12:2. It is the creative combination of royal and priestly dignity in Psalm 110, unique in the Old Testament, which has caught the writer's imagination, and which enables him to develop his own distinctive theology of the Messiah / Son of God who is also the perfect High Priest. It is thus true to say that the whole argument of the letter is founded on Psalm 110, even though it may be a formal exaggeration to describe it from a literary point of view as in its entirety a 'homiletical midrash' on the psalm. 27 With this in view, we now consider in more detail the seven major expositions outlined above.

\section{Psalm 8:4-6 in Hebrews 2:5-18}

The theme of the Son's superiority to angels has been set out in 1:4-14 on the basis of his superior dignity and creative power. Hebrews 2 by contrast establishes his superiority to angels, paradoxically, on the basis of his humiliation. In order to be a perfect saviour for humanity (not for angels, v. 16), he must be totally identified with the human condition, which is one of lower status than the angels (v. 9). His temporary humiliation was therefore an essential prerequisite for his saving work, by achieving which he has gone beyond anything that angels could offer. In order to establish this argument the writer draws

${ }^{26}$ For an extensive examination of the use of the psalms in Hebrews, see S. Kistemaker, The Psalm Citations in the Epistle to the Hebrews (Amsterdam: van Soest, 1961).

27Buchanan, To the Hebrews, xix. See discussion at n. 7 above. 
on a section of Psalm 8 which (a) speaks of the human condition, (b) contrasts it with that of angels ${ }^{28}$ as being 'a little lower', and (c) uses the evocative term 'the son of man'. The last point provides a convenient handle to enable the writer to find the fulfilment of this psalm in Jesus, the 'Son of Man'.29 The high destiny predicted in the psalm has not yet been fulfilled for humanity as a whole, but 'we see Jesus' (v. 9), in whom it has indeed been fulfilled, and who through his solidarity with humanity can thus lead his 'brothers and sisters' (vv. 11-13) up to the same destiny. But in order to do so he who was in his essential nature (as chapter 1 has demonstrated) above the angels must first share the human condition of being 'lower than the angels' through the experience of incarnation and suffering. This necessity is squared with the exalted status of the Son by the writer's observation of the term 'for a little

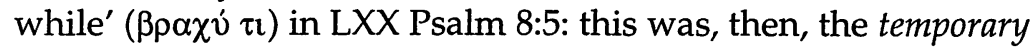
humiliation of one previously of higher status, 30 a means to the greater end of universal dominion which according to the psalm belongs to Jesus, and through him to humanity. This is a christological interpretation, inspired not by 'scientific exegesis' of the psalmist's intention alone but by a conviction of the role and status of Jesus which takes advantage of the happy

\footnotetext{
${ }^{28}$ The reference to angels where most English versions (probably rightly) refer to God is apparently not an arbitrary alteration by the writer of

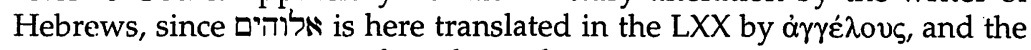
same interpretation is found in the targum and in later Jewish commentaries on the psalm.

${ }^{29}$ The fact that this writer, in common with most of the writers of the New Testament, does not use the title 'Son of Man' elsewhere does not mean that he and his readers would not have been aware of its prominent use as a title of Jesus in the gospel tradition. It is hard to imagine that any Christian, particularly a Greek-speaking Christian, after the middle of the first century could have heard the phrase viò $\dot{\alpha} v \theta \rho \omega \dot{\pi} \pi \mathrm{v}$ without thinking of Jesus.

${ }^{30} \mathrm{~A}$ temporal sense ('for a short time') is theoretically possible both for the

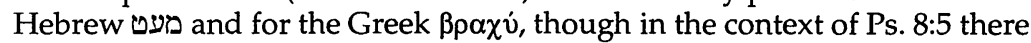
is little doubt that the whole phrase originally meant '[only] a little less than God' (as a statement of the extraordinary dignity of humanity as God's vice-gerent) rather than 'for a little time less than the angels' (as a statement of temporary humiliation). The use of the words of this verse by the writer to the Hebrews is creative rather than simply exegetical!
} 
occurrence of the 'Christian' phrase 'son of man' in the psalm and of the ambiguity of the words of v. 5 'for a little while lower than the angels' ( $\left.\beta \rho \alpha \chi v v^{\prime} \pi \alpha \rho^{\prime} \dot{\alpha} \gamma \gamma \varepsilon \dot{\lambda} \lambda o v \varsigma\right) .{ }^{31}$ It is the solidarity of Jesus as 'son of man' with the rest of humanity, and the high destiny for which humanity has been created, which controls the writer's understanding of the psalm, and enables him to use it as the basis for establishing in the rest of chapter 2 that, as the representative man, Jesus fulfils a role beyond the reach of angels.

\section{Psalm 95:7-11 in Hebrews 3:7-4:13}

Extensive consideration of this second exposition will appear below.

\section{Psalm 110 in Hebrews 5:5-7:28}

Although Psalm 110 has clearly already been in the writer's mind since his use of its first verse in $1: 3$ and $1: 13$, only at 5:57:28 does this psalm become the dominating scriptural text, with the focus now especially on v. 4 . It is clearly essential to the author's purpose that Jesus should be compared with and declared superior to such a central institution of Israel's religion as the Aaronic priesthood, but Jesus was not a priest, nor did he belong to the tribe of Levi from which alone the official priesthood must be drawn. Psalm 110:4, however, offers a solution to this dilemma by pointing to a different 'order' of priesthood, one which came from a non-levitical (indeed nonIsraelite) source in the mysterious Jebusite king Melchizedek, and one which, in sharp contrast to the Levitical priesthood of the Old Testament, combined the royal and priestly functions in a single person. This radically different kind of priesthood is, moreover, according to Psalm 110:4, instituted by an irrevocable divine oath, and is to be 'for ever'. All these points from this single verse are picked up by the writer in the course of his lengthy discussion of the superior priesthood of the Son and every word of the verse is exploited to the full. The specific mention of Melchizedek opens up a rich vein of scriptural associations, since the one other place in the Old Testament where Melchizedek appears, Genesis 14:17-24, also involves

31See notes 28 and 30 above. 
Abraham, the ancestor of Levi. This passage too is therefore discussed at some length in a subsidiary exposition (Heb. 7:1$10)$, with the same intention of exalting Melchizedek and his 'order' over the Levitical establishment. All the details of this elaborate argument cannot be considered here, but it is clearly the result of careful study and thought on the implications of Psalm 110:4 in the light of its background in Genesis. It involves some rather imaginative steps (particularly the implications drawn in Heb. 7:3 from the Old Testament's silence concerning Melchizedek's origin and family!), but the argument as a whole results from responsibly tracing a theme of biblical theology in the light of the writer's conviction that in Jesus God's redemptive purpose has reached its destined culmination.

\section{Jeremiah 31:31-34 in Hebrews 8:1-10:18}

Jeremiah's great prophecy of a new covenant (which is surprisingly not cited directly anywhere else in the New Testament) ${ }^{32}$ forms an obvious basis for the writer's argument that the old order was flawed, and a new and better covenant must take its place. After explaining that it is right for the high priest of the heavenly sanctuary to operate under a 'better' covenant based on 'better' promises $(8: 1-6)$, the writer quotes the Jeremiah text in full in 8:8-12, followed by a very brief expository comment on what the promise of a new covenant implies about the status of what went before $(8: 13)$. The Jeremiah text does not then explicitly appear again until 10:1617 , to round off the argument, but all that goes between these two quotations contributes to the reader's understanding of why the old covenant needed to be replaced. The second quotation in 10:16-17 is not of the whole Jeremiah passage but of selected clauses which focus not so much on the newness of the covenant as such, but on its basis in the 'internalised' law and the effective forgiveness of sins. This is the theme which has occupied chapters 9 and 10, the inadequacy of the former sacrificial system to deal effectively and permanently with the alienation caused by sin. That was the problem underlying

32It does, however, clearly lie behind the language about a 'new covenant' at the Last Supper (Lk. 22:20; 1 Cor. 11:25), and Paul's teaching about the new covenant, with its contrast between 'letter' and 'spirit', in 2 Cor. 3. 
Jeremiah's prophecy of a radically new approach to the relationship between God and his people, and in the one perfect sacrifice of Christ the problem has been solved, and Jeremiah's prophecy fulfilled. While in this exposition the writer does not, as in others, keep on returning to his scriptural text explicitly, its theme governs the whole of the intervening discussion until it returns with a triumphant Q.E.D. at the end. Compared with the subtlety of argument we have noted in previous expositions, this exposition is, in Longenecker's words, 'a straightforward piece of biblical exegesis', 33 taking the words of Jeremiah in their proper contextual sense and identifying their fulfilment in the messianic age. The means by which the problem of sin is finally dealt with may not have been specifically present in Jeremiah's mind, but it involves no distortion of the significance of his words to identify it in the single sacrifice of Christ to take away sins once for all.

The remaining three expositions can be dealt with more briefly here, since they have already been described above when defending their inclusion in the list of 'expositions'.

\section{Habakkuk 2:3c-4 (LXX) in Hebrews 10:32-12:3}

In this exposition of a modified form of the LXX ${ }^{34}$ of the Habakkuk text, it is again the theme rather than the specific words of the Old Testament quotation which governs the

33Longenecker, Exegesis, 184. Cf. his quotation there of Caird, 'a perfectly sound piece of exegesis'.

${ }^{34}$ The LXX already differs considerably from the Hebrew. Apart from the addition of some words from Is. 26:20 (LXX) at the beginning, the quotation in Hebrews modifies the LXX in three significant ways: (1) the

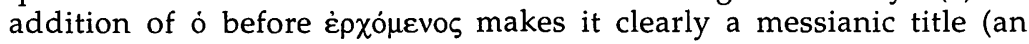
interpretation probably intended in the LXX, but absent from the

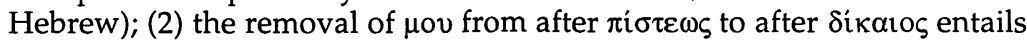
that the person described is God's righteous person, and the $\pi$ i $\sigma \tau i \zeta$ is that person's attitude of trust, not God's faithfulness [several MSS of LXX have the same order as Hebrews, but this is generally assumed to be under the influence of the NT use of the text]; (3) the reversal in order of the two clauses of v. 4 has the effect that $\dot{\pi} \pi \sigma \tau \varepsilon i \lambda \eta \tau \alpha l$ can be understood of a failure on the part of the $\delta i \kappa \alpha l o g$, whereas the subject in LXX is probably

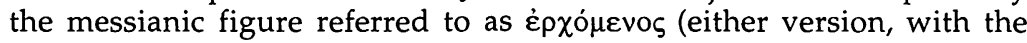
mention of my [God's] soul being displeased, is far distant from the Hebrew where the נפש is that of the non-upright person). 
succeeding discussion. There is no further explicit citation of the Habakkuk text after its initial introduction in 10:37-38, though the preceding verses (32-36) have already so clearly depicted the problem faced by the readers that no further analysis of the wording of the text is needed in order to establish its relevance to them. Indeed, in contrast with Paul's rather more creative use of this same text in Romans 1:17 and Galatians $3: 11,35$ the application in Hebrews of the key clause

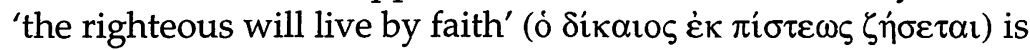
really rather modest and straightforward!36 The exposition thus follows a similar line to that of Jeremiah 31:31-34, in that the verbatim quotation of the text is followed in the next verse (10:39) by a brief clarification of its theme, with the focus on the

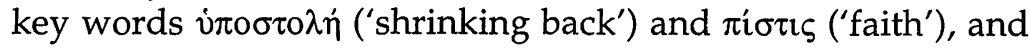
on the contrasting fates which follow from them, but from that point on that theme is developed in new ways, particularly by the majestic pageant of living examples of faith drawn from the Old Testament which makes up chapter 11. The key word of Habakkuk 2:4, $\pi i \sigma \tau \imath \varsigma$, thus governs all that follows, and the examples offered serve together to explain and reinforce the

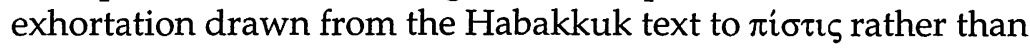
$\dot{v} \pi \circ \sigma \tau 0 \lambda \dot{\eta}$, which is the central concern of this part of the letter.

\section{Proverbs 3:11-12 in Hebrews 12:4-13}

When the writer introduced Habakkuk 2:3c-4 in chapter 10 he simply assumed that the challenge of the ancient text was directly applicable to his readers. Now he makes that assumption explicit: the exhortation in Proverbs 'addresses you

\footnotetext{
35It is suggested by some commentators that the whole argument of Romans 1-8 is structured around this text, with chapters 1-4 'expounding'

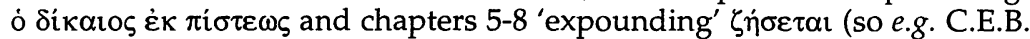
Cranfield, The Epistle to the Romans vol. 1 [Edinburgh: T. \& T. Clark, 1975] 28,103 , etc.). If that is Paul's intention, it is undeniably 'creative' and stands in some tension with what Hab. 2:4 is actually talking about in context!

${ }^{36}$ The rearrangement of the LXX text (see note 34 above) has produced

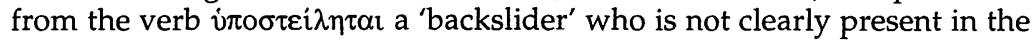
use of that word in either Hebrew or LXX, but in both versions there is a contrast between the faithful sikalos and an opposite attitude, which is picked up and sharpened by Hebrews' rearrangement of the clauses.
} 
as sons'. There is nothing controversial in such an assumption where a piece of proverbial wisdom is concerned, and the reflections of Proverbs on the fatherly discipline which God exercises over his children are a natural basis for the writer's attempt to help his readers to understand their present suffering. The exposition in vv. 7-11 stays close to the Proverbs text, exploring the significance of its words and images, before closing (vv. 12-13) with an appropriate call to endurance in the light of the theological perspective on suffering which the Proverbs text has provided.

\section{The Mount Sinai Motif in Hebrews 12:18-29}

As explained above, the basis in this case is not a formal quotation of a single text, but rather the motif of the fearsome mountain found in the Sinai account, drawing on some of the striking images and phrases of Exodus 19-20, and exploiting the theme of the quaking of the mountain by alluding also to the eschatological shaking of heaven and earth in Haggai 2:6. But whereas in other expositions the Old Testament text has provided a positive promise or exhortation for the readers to take hold of, in this case the Old Testament image represents the terrifying past which they have left behind, while all that is new and positive is taken up in the contrasting image of Mount Sion, which, despite its Old Testament name, is described in terms which, where they relate to the Old Testament at all, do so more by contrast than by continuity. But in so far as a passage of scripture has provided the basis for, and remains in view throughout, an extended discussion, this too falls roughly within the understanding of 'exposition' with which .we have been working.

\section{Summary}

To survey these six 'expositions' is to show that they are not uniform. They present us not with a standard 'technique' which can be applied in the same way to any chosen text, but rather with a varied series of examples of how this writer naturally develops his thoughts and arguments around Old Testament passages which, in ways appropriate to the differing subjectmatter, form the continuing basis of his thought rather than 
being quoted in passing and then left behind. In some cases the application of the scripture passage to his theme is relatively obvious and uncontroversial (notably in the use of Je. 31:31-34; Hab. 2:3c-4 and Pr. 3:11-12). In other cases it is more creative, even to our minds obscure (notably in his argument from Ps. 8), or operates by contrast rather than by positive application of the text (in the reference to Mount Sinai). In some cases the relevance of the text is quite simply expressed (notably in the exposition of Pr. 3:11-12); in others it takes off into quite complex patterns of argument (as in his use of Ps. 110:4), though the 'base' text remains in view throughout. Fundamental to his expositions is the conviction, so memorably set out at the opening of the letter, that in Jesus God has spoken his last and perfect word, and that all that was written in the Old Testament is to be understood in relation to its fulfilment in the Son. That being so, it is his duty and pleasure to search the Old Testament scriptures for indications of the fulfilment which was to come, and to draw out from those same scriptures in a varied and creative way for his readers how they should now think and live in the light of the coming of the Son.

\section{Hebrews 3-4 as an exposition of Psalm 95}

Discussion of the exposition of Psalm 95 has been reserved until now because, while it can no more be described as 'typical' of the author's method than any one of the others, this exposition demonstrates some of the distinctive characteristics of the writer's use of Scripture, and in particular his capacity for the sustained application of a key text to the situation of his readers. After the full quotation of Psalm 95:7b-11 in 3:7-11, parts of those verses are quoted again in $3: 15 ; 4: 3,4,7$, and words from the psalm provide the raw materials for the whole argument of 3:7-4:13.

Psalm 95 is familiar to Anglicans as the 'Venite', traditionally sung or said at Morning Prayer. ${ }^{37}$ After an

37It is much to be regretted that the 1980 Alternative Service Book of the Church of England has arbitrarily emasculated this great psalm by replacing vv. $7 \mathrm{~b}-11$ with a weak amalgam of some of the words of $v .7$ 
opening call to reverent and joyful worship of God as the creator and king of the earth and of all its people, the psalmist issues a memorable call to listen to what God has to say 'today', and underlines this appeal by reflecting on Israel's failure to listen in the past, when they hardened their hearts in rebellion in the wilderness. It was that rebellion which led to their forfeiting the 'rest' which God had promised them in Canaan under the leadership of Joshua.

It is this latter part of the psalm which the writer of Hebrews picks up and deploys extensively throughout 3:7-4:13, as a warning to his readers not to repeat Israel's mistake. It was those who followed Moses in the wilderness who rebelled; now he is writing to the followers of a greater than Moses (3:1-6), and fears that they too may be in danger of a similar failure. They too can hear God's voice 'today', and must not close their ears to it; otherwise they in their turn may find themselves excluded from the 'rest' promised to them under the leadership of the new and greater Joshua (the 'coincidence' that the name of Jesus is the same as the Greek form of that of his Old Testament predecessor is not overtly exploited, but can hardly have escaped the writer's attention).

So much might have been said in very few words. Paul mounts a similar argument in 1 Corinthians 10:1-13, and is content to recall the historical narratives and to draw the obvious typological conclusions without further scriptural reference. Hebrews, however, has chosen to give added weight to the warning by drawing on a psalm which itself meditates on the significance of the wilderness events and turns them into an exhortation for a later generation. Rather than repeat the familiar stories from the Pentateuch, the writer dwells on this psalm and subjects its words to careful and creative examination in order to maximise its pastoral impact on his readers' situation.

The psalm itself has already made the significant step of assuming that what happened in the wilderness can serve as a model for a later generation. The psalmist has

with words from Ps. 96:13, thus removing the challenging and uncomfortable exhortation which is in fact the part of Ps. 95 which Hebrews chooses to expound! 
'contemporised' the pentateuchal narratives for his own day, apparently not on the basis of a specific typological conviction that his own period was in any unique way the counterpart of the wilderness events, but rather by finding universal principles in the experiences of Israel's formative period. For Hebrews this universalisation might well have been enough to justify his use of the psalm, but in fact he has also set it in the context of a more specific typological connection. The early Christians for whom he is writing are not just another generation of Jews, but are the people of the New Exodus, following the one who is greater than and has now superseded both the leading figures of the original exodus event, Moses and Joshua. They thus live in days every bit as formative as the exodus period, and in as much as their leader is now no less than the Son of God, their response to him and to the words of God which they hear through him is of even more ultimate significance. The 'today' of which the psalmist speaks is for them a crucial time of decision; there has never before been a 'today' of such ultimate importance.

But 'today' does not last for ever. That was the fatal experience of the original exodus generation, and by their intransigence at Meribah and Massah ${ }^{38}$ they forfeited the promise of final 'rest'; their 'bodies fell in the wilderness' and 'they were unable to enter because of unbelief' (3:17-19). So these Christians must also now respond, and exhort one another to respond, 'as long as it is called "today"', if they too are not to lose their promised 'rest'. So the writer returns insistently to the key word 'today' $(3: 7,13,15 ; 4: 7-8)$, assuming that it is as applicable to his readers as it was to those to whom the psalmist (explicitly identified as David, 4:7) originally addressed his words.

So far we have a relatively straightforward exposition not, as in 1 Corinthians, of the wilderness narratives but rather of the psalm which is itself already expounding their significance for a later generation. The psalm is one of

38The LXX version quoted in Hebrews does not present the מסה and of Ps. 95:8 as proper names (cf. Ex. 17:7), but the historical occasion of Israel's disobedience would be likely to be familiar to his readers, and is clearly indicated by the wilderness setting of the psalm. 
exhortation and warning, and the writer has used it effectively for the same purpose. The added dimension of the coming of a new Moses and Joshua figure in Jesus adds weight to that exhortation, and focuses its specific relevance, but in no way distorts the writer's responsible use of the scriptural text.

But there remains an important question for these Jewish Christians. What, for them, is the 'rest' which they are in danger of losing? The question is taken up in 4:5-11. Because the psalmist, writing centuries after the exodus events, could still appeal for response 'today', the writer infers that the rest he refers to cannot be only a lost opportunity in the distant past, but remains available to the people of God. They too have something precious to lose, and must 'make every effort to enter that rest', and not to forfeit it through disobedience to the voice of God when they hear it 'today'. The 'rest' towards which Joshua was leading the wilderness generation, and which they lost, was that of settlement in the promised land, after the bondage in Egypt and the nomadic existence in the wilderness. To find a more permanent application for the words of the psalm, the writer of Hebrews now does a little imaginative 'concordance work', and finds in Genesis 2:2 another very significant use of the term 'rest': 'God rested on the seventh day from all his works'. Noting that in Psalm 95:11 God speaks of ' $m y$ rest', Hebrews understands this not only as the rest which God gives but also as the rest which God himself enjoys. So he recalls God's 'rest' when he had completed the work of creation (4:3-4). As God himself enjoyed rest after labour, so it is also for his people. They too have their 'sabbath', when they will 'cease from their labours' (4:9-10). It is such a 'sabbath' which lies ahead for the Christian readers of Hebrews, and which they risk losing by disobedience.

The writer does not spell out what form this sabbath rest is to take, but later in the letter he will turn their eyes to heaven as the ultimate goal (11:13-16; 12:22-23), and it seems probable that is the 'rest' he has in view here. There the people of God will share God's own rest. To stop short of that consummation would be unthinkable. In the light of that ultimate sabbath, therefore, the response made 'today' takes on eternal significance, beside which the mere possession of the 
land of Canaan under the first Joshua seems of quite minor importance. For the Christian readers of Hebrews the stakes are higher even than they were for the Israelites in the wilderness. For the author of Psalm 95 too the issue of the possession of Canaan was past history, but the wording of the psalm does not allow us to say just what sort of 'rest' he envisaged as now likely to be forfeited through disobedience. But the writer of Hebrews, by drawing the sabbath rest of Genesis 2 into his exposition, has made clear the ultimate significance of his people's response to the voice of God, and in so doing has invested his pastoral warning with greater urgency even than that of the psalm.

By exploiting the words 'today' and 'rest' in Psalm 95, therefore, the writer has added force to the hortatory impact of the psalm, and applied it more directly to the new situation in which Christian Jews found themselves. But in so doing he has not come into conflict with the original meaning and purpose of the psalm, but merely sharpened and contemporised its impact. This is expository preaching of a sort most evangelical pastors today would recognise as legitimate and indeed necessary, even if the creative way Genesis $2: 2$ is brought into the exposition would perhaps not appeal to all of them!

The writer goes on to speak of the penetrating effect of God's Word as like that of a two-edged sword (4:12-13). In chapters 3-4 he has wielded that sword with vigour, and to good effect.

\section{The Distinctive Expository Method of Hebrews}

The material surveyed here amply justifies the conclusion that the extended exposition of biblical texts is a characteristic of the letter to the Hebrews in a way which is true of no other New Testament writing. It seems to be the instinct of this writer to have recourse to Scripture as the basis for each succeeding phase of his writing, whether its tone is primarily doctrinal or primarily hortatory. With the notable exception of the first chapter, the texts which form the basis of the letter are not merely quoted as proofs for an argument set up on other grounds, but are examined often at some length both in terms 
of their relevance as a whole to the new situation to which he is now applying them and in some cases with regard to the significance of individual words and phrases which can be explored to fill out and sharpen that application.

In most of the 'expositions' we have considered the primary application of the text is quite straightforward, in that the writer treats the text in accordance with what appears to be the meaning and application intended by the original author in a way no modern preacher need feel uncomfortable with. The writer may, of course, go beyond what the original author would have had in mind, but this is a matter of extension, not of misappropriation. In the course of his exposition he may draw in a number of other Old Testament texts to help him to develop his theme, leading to some creative extension of the thought of the base text. Some of these 'subsidiary' texts may then themselves also be subjected to brief 'expository' treatment (see e.g. Heb. 2:13-14 [Is. 8:17-18]; 4:4-10 [Gn. 2:2]; 7:110 [Gn. 14:17-20]; 10:5-10 [Ps. 40:6-8]; 12:26-28 [Hg. 2:6]), but always within the framework of the exposition of the primary text.

I referred above to the application of most of the texts as 'straightforward'. It is always dangerous to talk about the 'natural' or 'obvious' meaning of a biblical text, since experience suggests that what is obvious to one reader may be far from obvious to another, especially if the latter belongs to a different age or culture. But what I mean is that most modern readers, however different their cultural context, can recognise as appropriate the way the writer of Hebrews decided to deploy his chosen texts so many centuries ago. Not that his use of them is particularly 'modern', but we in our day can follow and approve and learn from the way he set about applying the 'two-edged sword' of the word of God to the special circumstances of his Hebrew Christian readers. In a comparable context many of us might well choose to start from the same passages, and in some cases the way we would expound them might not differ very greatly in principle from his.

Of course there are occasions when his methods differ significantly from the standards of modern historico-critical or expository methods. Few of us would wish to conclude baldly 
that the worship of the angels in Deuteronomy 32:43 LXX was in fact directed towards the Son (Heb. 1:6), ${ }^{39}$ or that the 'Lord' to whom the praise of Yahweh in Psalm 102:25-27 is addressed is in fact the Son (Heb. 1:10-12). Few modern scholars believe that, whatever the textual and lexical possibilities of the words he used, the author of Psalm 8 really intended to speak about a specific individual called 'the son of man' who would be temporarily placed below the angels (Heb. 2:8-9). Few of us would have thought that the lack of a curriculum vitae for Melchizedek in Genesis 14 was a pointer to an eternal Son of God (Heb. 7:3). Most of us would hesitate to adapt the LXX text of Habakkuk 2:3-4 (and still more the Hebrew underlying it) as boldly as Hebrews does. These and other such 'imaginative' uses of Old Testament texts are certainly not what we would call straightforward exegesis. Indeed it is probably true to say that they are not (and are not meant to be?) exegesis at all, if by that term we mean an attempt to discover the intended meaning of the text in its original context. What they are is christological interpretation.

The key to understanding the use of the Old Testament in Hebrews, as indeed in much of the New Testament, is to set aside our modern concept of 'objective exegesis' and to recognise that their biblical interpretation is done consciously and openly on the understanding that the Hebrew scriptures have found their true meaning in Jesus. All that went before was but 'a shadow of good things to come' (Heb. 10:1), just as the wilderness tabernacle was 'a symbol of the present time' (Heb. 9:9). Within that theological framework the sort of creative interpretation we have seen Hebrews engaging in from time to time makes perfect sense; the true significance of Old Testament scripture is found only with Christian hindsight.

${ }^{39}$ There used to be the further embarrassment that the clause quoted is from the LXX but does not appear in the received Hebrew text of Dt. 32:43. The fortunate discovery at Qumran of a much earlier Hebrew text of these verses, which includes a clause equivalent to that quoted by Hebrews, has however shown that the problem lay not with the LXX or with Hebrews, but with the Massoretic tradition. See J.T. Milik, Ten Years of Discovery in the Wilderness of Judaea (London: SCM, 1959) 24. 
In so using the Old Testament, the early Christian teachers and preachers were following faithfully in the pattern of interpretation established by the one who 'interpreted to them the things about himself in all the scriptures' (Lk. 24:27; cf. v. 44). ${ }^{40}$ Among those who followed this new interpretative model the writer of Hebrews was among the most consistent and creative.

The writer was a Jew of the first century, and his use of Scripture falls recognisably within that cultural context. W.L. Lane usefully summarises the ways in which Hebrews shares the interpretative methods of his Jewish contemporaries, and concludes that the principles by which he was guided in his approach to the Old Testament text and the forms of exposition he adopts were those with which he had become familiar from a life enriched by synagogue preaching' ${ }^{41}$ I would not wish to quarrel with this verdict as regards much of his handling of the text, but it needs to be added that what we find in Hebrews is not typical synagogue preaching, but the new approach to Scripture which was inevitable for a Jew who had come to follow Jesus, and for whom Jesus himself was now the interpretative key. A non-Christian synagogue hearer would no doubt have felt at home with the style of much of Hebrews' use of the Old Testament, but would have been bewildered by the theological context in which it was set, and therefore also by the results which followed.

What we have in Hebrews is a glimpse into the workshop of early Christian biblical interpretation, where those who came to the Jewish scriptures with a new christological perspective, while not turning away from their ancestral Jewish manner of arguing from Scripture, were learning and developing new interpretative approaches. Among these innovative but faithful Christian interpreters of Scripture, the writer of Hebrews, with his extended christological expositions of chosen Old Testament texts, stands out as one of the most effective, and one who, because of the form in which he has

40 See the famous conclusion on the nature and origin of early Christian use of the Old Testament by C.H. Dodd, According to the Scriptures, 109110.

${ }^{41}$ Lane, Hebrezus 1-8, cxix-cxxiv (quotation from p. cxxiv). 
written his pastoral appeal, allows us a fuller insight into the hermeneutical workshop than any other. We may not feel that at every point we can preach just as he preached, but it will be a sadly defective form of Christian proclamation and exhortation which cannot incarnate appropriately for our day the hermeneutical principles and the expository insights which he has bequeathed to us. 